\title{
Variations of Biochemical and Cellular Urine Parameters among a Healthy Lebanese Group
}

\author{
Aline Hamade ${ }^{1, *}$, Fadia Najjar², Tracy Dagher ${ }^{1,2}$ \\ ${ }^{1}$ Department of Biology, Laboratory of Therapeutic Innovation, Faculty of Sciences II, Lebanese University, Lebanon \\ ${ }^{2}$ Department of Chemistry and Biochemistry, Laboratory of Therapeutic Innovation, Faculty of Sciences II, \\ Lebanese University, Lebanon
}

Copyright@2017 by authors, all rights reserved. Authors agree that this article remains permanently open access under the terms of the Creative Commons Attribution License 4.0 International License

\begin{abstract}
Objectives: Urine analysis, a simple and inexpensive test, is the cornerstone in the evaluation of the kidney function and may reflect some pathophysiologies. Materials: A cross sectional study was carried out in Lebanese University of Lebanon. One hundred asymptomatic students and stuff were enrolled in this study. Urine samples were obtained from students and stuff and were tested by dipstick method and trypan blue for urine cell count. Results: Among all the samples, leukocyturia and hematuria were the most common abnormalities found with a prevalence of $39 \%$ and $24 \%$ respectively, followed by proteinuria (13\%), nitrituria (8\%) and glycosuria (8\%). Urinary abnormalities were more common in females than in males. Number of living urine cells was associated to the presence of glucose, proteins and leucocytes in urine ( $p=0.001, p=0.049$ and $p=0.027$ respectively). Urine viable cells were also significantly correlated with the gender $(p=0.000)$, alcohol and theine consumption $(p=0.023$, $\mathrm{p}=0.034$ respectively) and smoking status $(\mathrm{p}=0.003)$. Conclusion: Asymptomatic urinary abnormalities might be detected by urine screening. Our results confirm that gender and environment factors might affect urine composition.
\end{abstract}

Keywords Dipstick Urine Analysis, Kidney Function, Environmental Factors, Urine Analysis Screening, Urine Cell Count

\section{Introduction}

Traditionally, clinicians and researchers have relied on a skin biopsy or blood extraction as relatively accessible supplies for in vitro cell expansion and biological studies. Perhaps surprisingly, limited attention has been given to a totally noninvasive source, urine, which eliminates the discomfort associated with other procedures [1]. Urine may be a waste product, but it contains an enormous amount of information [2]. It represents an unlimited source of patient-specific kidney cells that can be harvested noninvasively. The greatest advantages of urine as a source of viable cells are the easy collection and less complicated ethical issues [3]. General urine examination includes macroscopic, chemical and microscopic urinalysis. The macroscopic analysis includes examination of urine appearance and color. The chemical examination includes specific gravity, qualitative presence of proteins, blood, nitrites, glucose, ketones, bilirubin, urobilinogens, etc. The microscopic examination refers to the presence of erythrocytes, leukocytes, epithelial cells, cylinders, bacteria, crystals, etc.

In recent years, urine has emerged as a source of urine cells [4]. Various cells may be encountered in the urine sediment. Cells of Hematologic Origin like Erythrocytes (RBCs), Leukocytes (WBCs), Neutrophils, Glitter Cells (a type of neutrophil seen in hypotonic urine of specific gravity 1.010 or less), Eosinophils (Although difficult to recognize in the usual wet preparation of the urine sediment) and Lymphocytes (although they are rarely recognized, a few small lymphocytes are normally present in urine).Other type of cells, like Epithelial Origin example Renal Epithelial Cells (or renal tubular epithelium), Renal Tubular Fat Bodies (renal epithelial cells or macrophages that have filled with fat or lipid droplets), transitional Epithelial Cells (Urothelial Cells) and Squamous Epithelial Cells. Finally, some Microorganisms Encountered in the Sediment example bacteria and yeast [5].

Urine analysis, a simple and inexpensive test, is the cornerstone in the evaluation of the kidney function. Serious renal diseases may be present without any symptoms. Proteinuria as well as hematuria may be the only early signs of renal disease [6]. Also, the presence of detectable nitrites in urine has been used to diagnose urinary tract infection. Urinary tract infection is very common with severe consequences on the kidney function leading to chronic kidney disease and hypertension if left untreated [7,8].

It is well known that various biological factors affect the metabolic composition of biological fluids. They are intrinsic 
(e.g. age, gender) and extrinsic (e.g. diet, smoking, stress, exercise). The urine composition is typical among all individuals but anatomical difference in the urinary tract between men and women can generate a difference in the number of urine cells.

Epidemiological data on the incidence and prevalence of chronic kidney disease in the pediatric population is currently limited, imprecise, and flawed by methodological differences between various data resources. It is estimated to be approximately 18 per million [6].

Furthermore, many factors could be the reason for changes in the urine composition or even in the number of urine cells. In this study, we searched for a correlation between the number of urine cells and different parameters involving gender, lifestyle, family history, environmental factors, medications and urine biochemical composition. The aim of this study was to investigate variability in the biochemical urinary profile and urine cell count between male and female in a Lebanese population. The dipstick urinalysis screening was also conducted to detect abnormal urinary findings in asymptomatic persons.

\section{Materials and Methods}

\subsection{Study Group}

The study population consisted of 100 Lebanese University personals ( 73 females and 27 males) whose ages ranged between 17 and 60 . All participants signed a written informed consent and completed a questionnaire about their nutritional habits, age, current health status, smoking habits, physical exercise, daily water intake, medicine intake and other factors that affect the quality of urine and urination, the presence of any pathology or disease family history, or any drug taking history.

\subsection{Urine Dipstick Chemical Analysis}

Appropriate containers (up to $100 \mathrm{ml}$ ) were sterilized before urine collection. The first micturition of the day was routinely avoided. Besides, only the mid-stream of urine was later on collected into sterile containers. Urine samples were collected from all the participants and urine were analyzed using a Dipstick. The usual volume of specimens was 50-100ml. Dipstick urinalysis was done using Multistix 10 SG (Siemens) and Clinitek Advantus Analyzer. The reagent strip contains tests pads for protein, blood, leukocyte esterase, nitrite, glucose, ketone, $\mathrm{pH}$, specific gravity, bilirubin and urobilinogen.

Urinalysis was considered abnormal, if the following findings were detected: $>5-10 \mathrm{RBC} / \mu \mathrm{l}$; hematuria; $1+$ or greater proteinuria (trace, $1+, 2+, 3+, 4+$ correspond to $10 \mathrm{mg} / \mathrm{dl}, \quad 30 \mathrm{mg} / \mathrm{dl}, \quad 100 \mathrm{mg} / \mathrm{dl}, \quad 300 \mathrm{mg} / \mathrm{dl}, \quad 1000 \mathrm{mg} / \mathrm{dl}$ respectively); $1+$ or greater glycosuria $(1+, 2+, 3+$ corresponds to $100 \mathrm{mg} / \mathrm{dl}, \quad 300 \mathrm{mg} / \mathrm{dl}, \quad 1000 \mathrm{mg} / \mathrm{dl}$ respectively); Positive nitrites; and $>25 \mathrm{WBC} / \mu \mathrm{l}$; leukocyturia.

\subsection{Urine Viable Cell Count}

The urine cell count was determined by the trypan blue exclusion test. Urine samples were then transferred into 15 $\mathrm{ml}$ tubes inside a tissue culture hood and these tubes were centrifuged at 900rpm for 5 minutes at room temperature. The supernatant were discarded and cells re-suspended in 500 $\mu \mathrm{l}$ of PBS (Dulbecco's Phosphate Buffered Saline, Sigma-Aldrich, USA), centrifuged again and re-suspended in 100 $\mu$ L DMEM- F12 (Dulbecco's Modified Eagle's Medium F-12 Ham, Sigma-Aldrich, USA) containing 10\% Fetal Bovine Serum FBS (Sigma-Aldrich, St. Louis, USA), 1\% penicillin/streptomycin and 1\% amphotericin B (PSA) (Lonza, Basel, Switzerland). The cell suspension was diluted $(1: 1, v / v)$ with trypan blue to reach $0.4 \%$. The number of viable cells was determined.

\subsection{Statistical Analysis}

Statistical analysis was performed using the ANOVA test followed by post hoc tests of Duncan or Turkey for more precision. The study of the evolution between 2 time points was performed using the paired samples Student t-test. Differences were considered significant for $\mathrm{p}$ values less than 0.05. All analyses were done using the GraphPad Prism software (version 7.0).

\section{Results}

\subsection{Description of the Sample}

Table 1 presents the main characteristics of each of the two groups: Male and females. In total, 100 samples were evaluated; they were aged between 17 and 60 years, 27\% males and $73 \%$ females. Moreover, we describe in Table 1 some variables, such as dwelling region, the blood group, time of urination per day, the presence of certain diseases, the consumption of caffeine, theine and alcohol, and the smoking status; there were no statistically significant differences between males and females regarding the listed characteristics. A significant difference in smoking status was observed, which is lower in female group compared to male group with a value of $\mathrm{P}<0.05$. (Table 1 )

\subsection{Urine Test Analysis and Cell Count}

Among all the parameters studied in the urine test, there was a significant difference in the number of leucocytes between females and males; 35 females and only 4 males had a considerable number of leucocytes ( $p$ value $=0.002$ ). 
Concerning the results of the cell count, there was a very significant difference between males and females; females showed a higher total cell count $(\mathrm{P}$ value $=0.036)$ and living cell count ( $p$ value $=0.000$ ) compared with males (Table 2).

Some subjects had more than one abnormality detected. Leukocyturia had the highest prevalence detected in 39\% of samples; proteinuria detected in 13\%; Hematuria detected in $24 \%$ and Glycosuria in only $8 \%$. The other abnormalities found were nitrituria with only $8 \%$ among all samples.

\subsection{Correlation between Number of Urine Living Cells, Metabolic Urinary Profile and Environmental Factors}

There was a correlation between the presence of glucose, proteins and leucocytes in urine $(\mathrm{p}=0.001, \mathrm{p}=0.049$ and $\mathrm{p}=0.027$ respectively) and the number of living cells. No significant association was observed between bilirubin, urobilinogen and blood with urine living cell count $(p=0.253$, $p=0.152$ and $p=0.134$ respectively) (Figure 1 ).

Table 1. Comparison of the characteristics of the samples (27 males and 63 females) using t-test for continuous variables and Fisher's exact test for dichotomous variables

\begin{tabular}{|c|c|c|c|}
\hline \multirow{2}{*}{ Characteristics } & \multicolumn{2}{|c|}{ Sample } & \multirow{2}{*}{$\mathrm{P}$ value } \\
\hline & Male (27) & Female (73) & \\
\hline Mean Age $( \pm S D)$ year & $30.37 \pm 12.50$ & $27.68 \pm 10,43$ & 0.282 \\
\hline $\begin{array}{c}\text { Dwelling region, n (\%) } \\
\text { Beirut/Mount Lebanon } \\
\text { North } \\
\text { South } \\
\text { Bekaa } \\
\end{array}$ & $\begin{array}{c}14 \\
7 \\
1 \\
1\end{array}$ & $\begin{array}{c}44 \\
20 \\
6 \\
3 \\
\end{array}$ & 0,981 \\
\hline $\begin{array}{c}\text { Blood group } \\
\text { A } \\
\text { B } \\
\text { AB } \\
\text { O }\end{array}$ & $\begin{array}{c}5 \\
3 \\
0 \\
15\end{array}$ & $\begin{array}{c}21 \\
8 \\
0 \\
40\end{array}$ & 0,504 \\
\hline $\begin{array}{c}\text { Urination per day } \\
<3 \text { times } \\
\text { Between } 3 \text { and } 5 \text { times } \\
>5 \text { times }\end{array}$ & $\begin{array}{c}5 \\
15 \\
7 \\
\end{array}$ & $\begin{array}{l}18 \\
39 \\
16\end{array}$ & 0,997 \\
\hline $\begin{array}{c}\text { Diabetes } \\
\text { No } \\
\text { Yes } \\
\end{array}$ & $\begin{array}{c}26 \\
1 \\
\end{array}$ & $\begin{array}{c}73 \\
0 \\
\end{array}$ & 0,083 \\
\hline $\begin{array}{c}\text { Uro-génital Diseases } \\
\text { No } \\
\text { Yes }\end{array}$ & $\begin{array}{c}27 \\
0\end{array}$ & $\begin{array}{c}72 \\
1\end{array}$ & 0,291 \\
\hline $\begin{array}{c}\text { Hypertension Diseases } \\
\text { No } \\
\text { Yes } \\
\end{array}$ & $\begin{array}{c}26 \\
1 \\
\end{array}$ & $\begin{array}{c}72 \\
1\end{array}$ & 0.145 \\
\hline $\begin{array}{c}\text { Caffeine consumption (\%) } \\
\text { No } \\
\text { Yes }\end{array}$ & $\begin{array}{c}4 \\
23\end{array}$ & $\begin{array}{l}20 \\
53\end{array}$ & 0.077 \\
\hline $\begin{array}{c}\text { Theine consumption (\%) } \\
\text { No } \\
\text { Yes }\end{array}$ & $\begin{array}{l}11 \\
16\end{array}$ & $\begin{array}{l}46 \\
27\end{array}$ & 0,903 \\
\hline $\begin{array}{c}\text { Alcohol consumption (\%) } \\
\text { No } \\
\text { Yes }\end{array}$ & $\begin{array}{c}21 \\
6\end{array}$ & $\begin{array}{l}60 \\
13\end{array}$ & 0,605 \\
\hline $\begin{array}{c}\text { Smoking status (\%) } \\
\text { Yes } \\
\text { No }\end{array}$ & $\begin{array}{l}14 \\
13\end{array}$ & $\begin{array}{l}60 \\
13\end{array}$ & $0,000^{*}$ \\
\hline
\end{tabular}


Table 2. Characteristic of the main urinary factors according to gender using t-test for continuous variables and Fisher's exact test for dichotomous variables

\begin{tabular}{|c|c|c|c|}
\hline \multirow{2}{*}{ Characteristics } & \multicolumn{2}{|c|}{ Sample } & \multirow{2}{*}{$\mathrm{P}$ value } \\
\hline & Male (27) & Female (73) & \\
\hline $\begin{array}{c}\text { Bilirubine } \\
\text { No } \\
\text { Yes }\end{array}$ & $\begin{array}{c}25 \\
2 \\
\end{array}$ & $\begin{array}{c}69 \\
4\end{array}$ & 0,747 \\
\hline $\begin{array}{c}\text { Urobilinogene } \\
\text { No } \\
\text { Yes }\end{array}$ & $\begin{array}{c}21 \\
6 \\
\end{array}$ & $\begin{array}{c}67 \\
6 \\
\end{array}$ & 0,057 \\
\hline $\begin{array}{c}\text { Ketone bodies } \\
\text { No } \\
\text { Yes } \\
\end{array}$ & $\begin{array}{c}27 \\
0 \\
\end{array}$ & $\begin{array}{c}71 \\
1 \\
\end{array}$ & 0,543 \\
\hline $\begin{array}{c}\text { Glucose } \\
\text { No } \\
\text { Yes }\end{array}$ & $\begin{array}{c}24 \\
3 \\
\end{array}$ & $\begin{array}{c}68 \\
5 \\
\end{array}$ & 0,491 \\
\hline $\begin{array}{c}\text { Proteins } \\
\text { No } \\
\text { Yes } \\
\text { Trace }\end{array}$ & $\begin{array}{c}12 \\
4 \\
11\end{array}$ & $\begin{array}{c}38 \\
9 \\
26 \\
\end{array}$ & 0,545 \\
\hline $\begin{array}{l}\text { Blood } \\
\text { No } \\
\text { Yes }\end{array}$ & $\begin{array}{c}23 \\
4\end{array}$ & $\begin{array}{l}53 \\
20\end{array}$ & 0,195 \\
\hline $\begin{array}{c}\text { Nitrites } \\
\text { No } \\
\text { Yes }\end{array}$ & $\begin{array}{c}27 \\
0 \\
\end{array}$ & $\begin{array}{c}70 \\
3 \\
\end{array}$ & 0.290 \\
\hline $\begin{array}{c}\mathrm{pH} \\
\text { Normal } \\
\text { Not normal }\end{array}$ & $\begin{array}{c}27 \\
0\end{array}$ & $\begin{array}{c}73 \\
0 \\
\end{array}$ & - \\
\hline $\begin{array}{c}\text { Density } \\
\text { Normal } \\
\text { Not normal }\end{array}$ & $\begin{array}{c}27 \\
0 \\
\end{array}$ & $\begin{array}{c}73 \\
0 \\
\end{array}$ & - \\
\hline $\begin{array}{c}\text { Leucocytes } \\
\text { No } \\
\text { Yes } \\
\end{array}$ & $\begin{array}{c}23 \\
4 \\
\end{array}$ & $\begin{array}{l}38 \\
35 \\
\end{array}$ & $0,002 *$ \\
\hline Total cell count & $171031.70 \pm 530187.19$ & $2129846.13 \pm 5237179.66$ & $0.036^{*}$ \\
\hline Viable cell count & $21970.88 \pm 73535.17$ & $604458.63 \pm 841368.65$ & $0,000 *$ \\
\hline Dead cell count & $149060.81 \pm 483678.16$ & $1525387.50 \pm 4693526.28$ & 0,076 \\
\hline
\end{tabular}




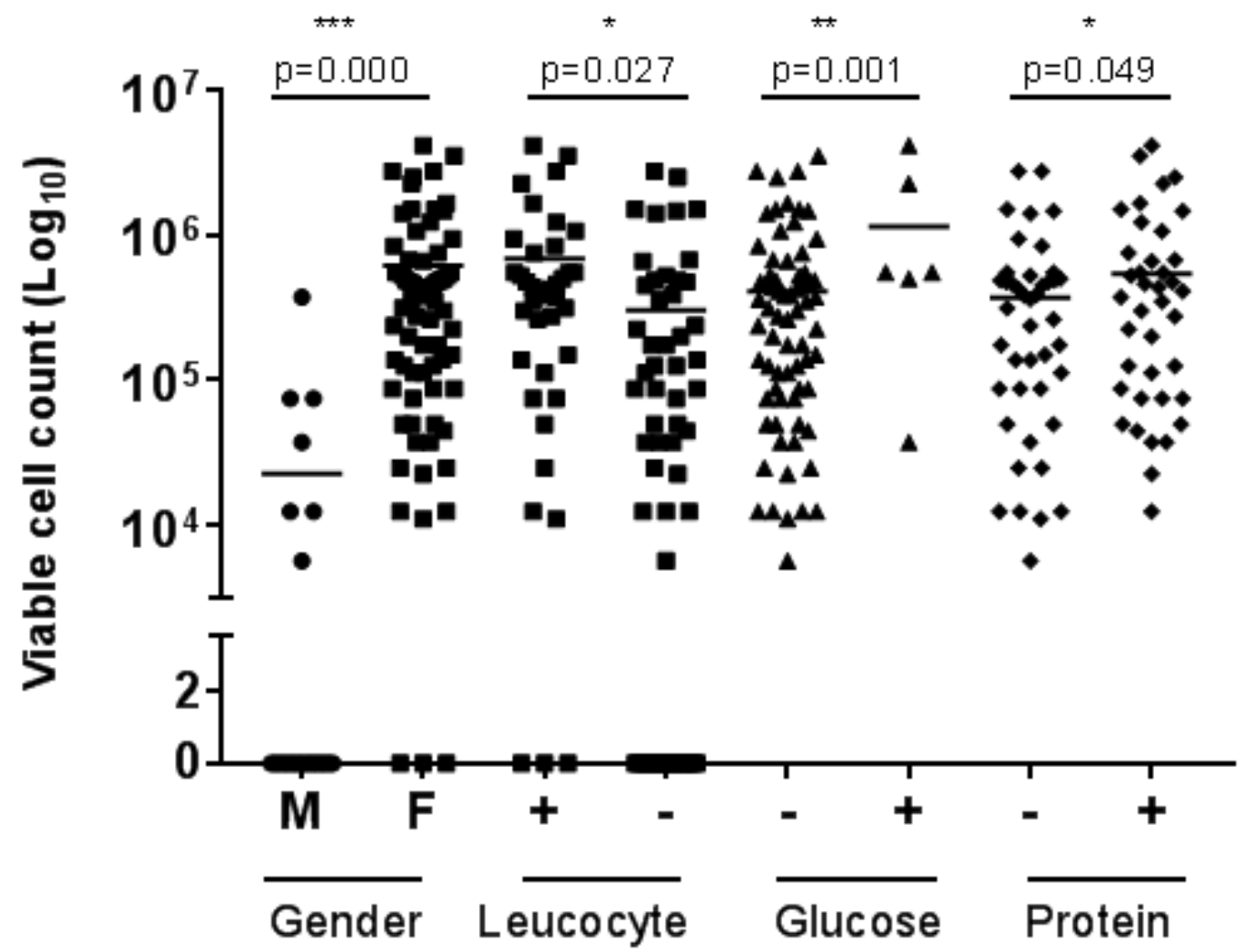

Figure 1. Correlation between viable cell count and many factors (gender, leucocyte, glucose and proteins) using t-test. ${ }^{*} \mathrm{p}<0.05,{ }^{* *} \mathrm{p}<0.01$, ${ }^{* * *} \mathrm{p}<0.0001$

Moreover, urine viable cells was significantly associated with the gender $(p=0.000)$, alcohol and thein consumption $(p=0.023, p=0.034$ respectively) and smoking status $(p=0.003)$ (Table 3$)$.

Table 3. Correlation between viable cells count and environmental factor using t-test. * $\mathrm{p}<0.05$, ${ }^{* *} \mathrm{p}<0.001,{ }^{* * *} \mathrm{p}<0.0001$

\begin{tabular}{|c|c|c|}
\hline Characteristics & $\begin{array}{c}\text { Viable cells mean } \\
(\text { Mean } \pm \text { SD })\end{array}$ & $P$ value \\
\hline $\begin{array}{c}\text { Gender } \\
\text { Male (27) } \\
\text { Female (73) }\end{array}$ & $\begin{array}{c}21970.88 \pm 73535.17 \\
604458.63 \pm 841368.65\end{array}$ & $0,000^{* * *}$ \\
\hline $\begin{array}{c}\text { Caffeine consumption (\%) } \\
\text { No (27) } \\
\text { Yes (73) } \\
\end{array}$ & $\begin{array}{l}647685.18 \pm 963741.94 \\
373030.05 \pm 668345.08 \\
\end{array}$ & 0,067 \\
\hline $\begin{array}{c}\text { Consumption of Thein/day } \\
\text { Non (43) } \\
\text { Oui (33) } \\
\end{array}$ & $\begin{array}{l}423647.09 \pm 702013.91 \\
150511.18 \pm 201858.77\end{array}$ & $0,034 *$ \\
\hline $\begin{array}{c}\text { Alcohol consumption (\%) } \\
\text { No (81) } \\
\text { Yes (19) } \\
\end{array}$ & $\begin{array}{l}503340.87 \pm 830748.31 \\
207793.84 \pm 262595.72\end{array}$ & $0,023 *$ \\
\hline $\begin{array}{c}\text { Smoking status (\%) } \\
\text { No (74) } \\
\text { Yes (25) } \\
\end{array}$ & $\begin{array}{l}551050.71 \pm 854376.12 \\
145637.64 \pm 242958.96\end{array}$ & $0,003^{*}$ \\
\hline
\end{tabular}




\section{Discussion}

Urine is often sampled from patients participating in clinical studies. Biological homeostasis occurs in humans, but little is known about the variability between genders of components found in urine. It is important to define the biochemical and cellular variance within a normal population before scientific or clinical conclusions are made regarding different pathophysiologies. This study investigates the variability of selected urine biochemical and cellular factor in a group of 100 healthy men and women and was conducted to determine the effect of gender on these factors. To our knowledge, this is the first report on dipstick urine analysis screening among asymptomatic university students and stuff in Lebanon.

Leukocyturia and hematuria was one of the most common abnormality found in our studied group. This was contrasted to other studies as in Egypt and Nigeria where proteinuria was the most common positive finding $[9,10]$. These two studies showed abnormalities among primary school children group.

A positive finding in our study was nitrituria that accounted for $3 \%$ of the studied group compared to the $1.5 \%$ in the Nigerian screening [11]. Urinary nitrites are produced by bacterial breakdown of dietary nitrates. The reliability of the nitrite test for urinary tract infections has been investigated by several workers, most of whom concluded that false positive results were rare and that the test had a higher specificity for urinary tract infections [12]. Specificity of urinary nitrite test is about $98 \%[13,14]$.

Our results showed more abnormalities among females groups than in boys. This was similar to the results of the Nigerian study [15], but contrasted with the results of the Egyptian study which showed that age and sex had no impact in the results of the screening done [9]. The finding of higher leucocytes and nitrites among females could be a reflection of higher rates of asymptomatic bacteriuria in the females of the studied group. Many studies showed that bacteriuria is 30 times more in females than in males, attributed to the fact that female have short urethra which predisposes them to ascending bacterial infection $[15,16]$.

The results showed that the presence of bilirubin, urobilinogen, the ketone bodies and blood in the urine of women and men donors has no significant effect on the number of urine viable cells. However, the presence of glucose and proteins in urine increase significantly the number of urine living cells. Glucose is normally filtered by the glomerulus and fully reabsorbed in the proximal tubule. The increase of the level of glucose in the urine (glucosuria) in diabetic donors can result in most cases by an elevation of blood glucose, this high level of glucose can alter the appearance of podocytes (epithelial cells the glomerular filtration barrier facing the urinary space). The high level of glucose makes the filtration membrane permeable to glucose and proteins of large size, which explains the high rate of protein in the urine. Furthermore, studies have been shown that exposure of glomerular cells at a high level of glucose may increase the synthesis of proteins of the extracellular matrix and growth factors. These factors can affect the viability cell, which explains the increase in the number of urine living cells in samples with glucose and proteins.

Our results showed that cigarettes, alcohol and theine consumption decrease significantly the number of urine viable cells. It's known that consumption of alcohol permanently alter renal filtration membrane, increasing urine volume by producing disturbances in electrolyte levels, which can affect cell viability in the urine.

\section{Conclusions}

In conclusion, urinary biochemical and cellular composition of a healthy population showed a distribution related to a significant extent to gender. We suggest that routine urinalysis should be part of screening of students at school and universities in Lebanon, and that further follow-up should be offered to determine the exact etiology of any abnormal finding.

\section{Acknowledgements}

The study was funded by the Lebanese UniversityLebanon.

\section{REFERENCES}

[1] Urine as a source of stem cells. Benda C, Zhou T, Wang X, Tian W, Grillari J, Tse HF, Grillari-Voglauer R, Pei D, Esteban MA.

[2] Joris Delanghe, Marijn Speeckaert (2013), Preanalytical requirements of urinalysis, Biochemia Medica, 24(1):89-104

[3] Fanny Oliveira Arcolino et al. (2015), "Human Urine as a Noninvasive Source of Kidney Cells”, Stem cells international, Article ID: 362562

[4] Kloskowski T, Nowacki M, Pokrywczyńska M, Drewa $\mathrm{T}(2015)$, "Urine--a waste or the future of regenerative medicine?”, Med Hypotheses, 84(4):344-9

[5] Karen M. Ringsrud(2001), Cells in the Urine Sediment, Chemistry | Hematology, 32(3): 153-155

[6] Philadelphia: Saunders; 2004. Kliegman: Nelson Textbook of Pediatrics.

[7] Kumar P, Clark M. Urinary tract infection. In: Kumar P, Clark M, editors. Clinical medicine. 4th edition. London: Harcourt Brace and Company; 1998. pp.548.

[8] Gorelick M, Shaw KN. Screening tests for urinary tract infection in Children: A meta-analysis. Pediatrics. 1999; 104:54. 
[9] Bakr A, Sarhan A, Hammad A, et al. Asymptomatic urinary abnormalities among primary school children in Egypt. World J Pediatr. 2007; 3(3):214-217.

[10] Akor F, Okolo S, Agaba E, Okolo A. Urine examination findings in apparently healthy new school entrants in Jos, Nigeria. SA J Child Health. 2009; 3(2):60-63.

[11] Akor F, Okolo S, Agaba E, Okolo A. Urine examination findings in apparently healthy new school entrants in Jos, Nigeria. SA J Child Health. 2009; 3(2):60-63.

[12] Powell H, McCredie D, Artchie M. Urinary nitrite in symptomatic and asymptomatic urinary infection. Arch Dis Child. 1987; 62:138-140.
[13] Sheifele DW, Smith AL. Home-testing for recurrent bacteriuria using nitrite strips. Am J Dis Child. 1978; 132:4648.

[14] Skelton IJ, Hogan M, Stokes B, Hurst JA. Urinary tract infections in childhood. The place of nitrite test. Med J Aust. 1977;1:882-886

[15] Akor F, Okolo S, Agaba E, Okolo A. Urine examination findings in apparently healthy new school entrants in Jos, Nigeria. SA J Child Health. 2009; 3(2):60-63.

[16] Travis LB, Brouhard BH. infections of the urinary tract. In: Rudolph AM, editor. Rudolph's Paediatrics.12th edition. Stamford: Appleton and Lange; 1996. pp. 1388-1392. 